\title{
A Corpus-based Study on the Influence of L1 on EFL Learners' Use of Prepositions
}

\author{
Huei-Chun Yuan \\ Department of English, National Taiwan Normal University, Taipei, Taiwan
}

\begin{abstract}
The present study is a corpus-based study which aims to investigate the occurrence of salient first language $\left(\right.$ Chinese $^{1}$ ) features found in learners' second language (English) written productions. AntConc (version 3.2.4) was adopted to analyze the learners' written data and to establish various categories of preposition misuses and L1 features. Tango ${ }^{2}$ was employed to provide suggestions for correction. Essentially, findings demonstrate that EFL learners may unconsciously produce L2 writings with L1 characteristics in their sentence productions. Results showed that the ten most frequently misused prepositions were by, at, in, to, for, on, about, of, with, and as. According to the results, it is suggested that, in regard to writing, teachers and educators can teach the use of prepositions through collocations to facilitate learners' knowledge and understanding for different prepositions through different contexts. The significance of the study is to raise learners' awareness as well as to provide reference for instruction for language teachers and educators.
\end{abstract}

Index Terms - first language (L1) transfer, preposition, interlanguage, written production

\section{INTRODUCTION}

With the growing pace of globalization and internationalization, English has become a dominant language in Taiwan. Learners at all ages possess their needs to master the language. However, due to various external factors, it has been argued that learners tend to perform better with receptive skills than productive skills. For some learners, receptive skills are mastered earlier than productive skills. Notwithstanding, it is without doubt that proficient productive skills lead to successful and fluent communication.

In Taiwan, how to enhance learners' competence in English writing has constantly been discussed. With the lack of opportunity to perform written communication with foreigners outside the classroom setting and complexity of elements in the syntax, lexis, and discourse level (Bennui, 2008), English writing continues to be a challenging subject for many learners. Furthermore, Bennui (2008) stated that many teachers tend to neglect the problem of learners' mother tongue and culture interfering in their English written productions. These types of problems may often occur for English L2 learners, especially when their L1 does not own a similar grammar system (Barrett and Chen, 2011).

Thus, the goal of the present study aims to detect L1 features found from learners' written productions, specifically in terms of learners' preposition usages. Detecting misuses is a principle means to solving the problem. It may help to raise learners' awareness as well as to provide reference for instruction for language teachers and educators.

\section{LITERATURE REVIEW}

\section{Difficult Elements of English Grammar}

Among the elements of English grammar, articles and prepositions have often been claimed as the most common grammatical error made by non-native speakers and may apparently be the most difficult elements of English for non-native speakers to master (Chodorow, Gamon, and Tetreault, 2010). In written discourse, articles and prepositions altogether account for $20 \%$ to $50 \%$ of all grammar errors made by second language learners (Dalgish, 1985; Diab, 1997; Izumi et al., 2003). Tetreault and Chodorow (2008) found that prepositions are among the most common type of usage error in writings of English as second language (ESL) learners in China. These claims have proved evident in many EFL learners' writings. Previous studies have also verified these claims. For example, Barrett and Chen (2011) investigated the potential errors made by Taiwanese college students and found that learners encountered problems using English articles in terms of distinguishing between a definite and indefinite noun phrase. Results also presented that more errors were made with plural nouns than with mass/non-count nouns. Another study conducted by Mahmoodzadeh (2012) looked into the misusages of prepositions made by 53 adult Iranian EFL intermediate learners. A translation task was performed to measure the participants' usages of prepositions. The researcher reported that participants of the study made errors related to wrong use of prepositions (wrong use) and redundant use of prepositions (redundancy) more frequently than omission of prepositions. It was implied that Iranian EFL learners tend to suffer from producing English prepositions which are grammatically redundant or wrong.

\footnotetext{
1 In the present study, "Chinese" refers to the official language used in the Republic of China, Taiwan.

2 An online collocation dictionary provided by the Natural Language Processing Lab at the Department of Computer Science, National Tsing Hua University (source: http: //candle.fl.nthu.edu.tw/collocation/webform2.aspx).
} 
So far, a number of studies have investigated the misuse of prepositions made by non-native learners of English according to the types of preposition errors, for example Tetreault and Chodorow (2008) reported in their study types of preposition misuses including (1) incorrect selection (e.g., "we arrived to the station"), (2) extraneous usage (e.g., "he went to outside"), and (3) incorrect omission (e.g., "we are fond null beer"). From a different perspective, Huang and Chen (2011) discovered three main types of common preposition misuses in the Taiwanese learners' corpus, including verb-preposition errors, preposition-noun errors, and adjective-preposition errors. Among the three types, preposition-noun errors ranked as the most frequent type of misuse, followed by verb-preposition errors, and lastly adjective-preposition errors. Although misuse of prepositions in written discourse is quite prevalent in the field, it continues to be an important issue for researchers, educators and teachers.

Research into prepositional errors has revealed that misuse of prepositions is quite common for EFL and ESL learners. One reason articles and prepositions may become quite problematic for EFL learners is because misuse of articles and prepositions do not easily cause communication breakdowns (Brender, 2002). However, in written context, inaccurate usages of articles and prepositions may cause a degree of ambiguity for the audience. In particular, prepositions are hard to master because it contains challenging and complex features in terms of their variety. They serve a great variety of linguistic functions (Tetreault \& Chodorow, 2008).

\section{Concept of Language Transfer}

According to Kohn (1986), the general concept of transfer is widely known as the effect of the interference of EFL learners' native language when producing L2 output. Transfer is also known as a process which involves learners' interlanguage behavior towards input of knowledge and transformation of input data into production of meaningful output. From this perspective, transfer inevitably shapes learners' production as well as process. In particular, this transfer portrays as one of the major factors to impede learners' interlanguage competence and performance. The definition of transfer has been discussed by Odlin (1989) from a general principle stating that "transfer of language" not only is influenced by learners' mother tongue but also is an interference of any other language learners possess knowledge on. This is also referred to as "cross-linguistic influence." Moreover, Ringbom's (1992) concept of transfer is known as "L1 transfer." From a different perspective, Ringbom's definition for L1 transfer is defined as "the influence of L1-based elements and L1-based procedures in understanding and producing L2 text" (Ringbom, 1992, p. 87). Thus, the concept of language transfer, also known as L1 interference, cross-linguistic influence, or L1 transfer, is a significant factor determining learners' learning and acquisition.

\section{Previous Studies on the Influence of L1}

Language learners' L1 continues to play a significant role in the acquisition of an L2 (Huang, 2010). Earlier research has reported on the emergence of mother-tongue influence found in non-native learners' productions. For example, Mahmoodazdeh (2012) claimed that Iranian EFL learners tend to suffer from producing English prepositions which are grammatically redundant (e.g., went to home) or wrong (e.g., depends to) in a translation task. These types of problems may often occur for English L2 learners, especially if their L1 does not have such a system (Barrett and Chen, 2011). According to the study, it was suggested that Iranian syllabus designers and material developers consider the level of cross-linguistic difficulty in the selection of course books. Huang (2010) investigated the potential influence of L1 (Chinese) on L2 (English) communication with a group of Chinese-speaking English as an additional language (EAL) learners. It was encouraged that instructors raise their awareness of the similarities and differences between learners' L1 and English to better inform their teaching. By the same token, Sersen (2011) conducted a study on increasing students' awareness of their L1 influences to improve the quality of writing. Positive results implied that enhancing awareness of learners' L1 influence can improve students' quality in L2 writing.

Previous research has demonstrated that the interference of L1 inevitably occurs and may hinder fluent productions for L2 learners and will bring a degree of influence on learners' L2 productions. However, seldom research on L1 transfer has been conducted on prepositions (Chodorow, Gamon, \& Tetreault, 2010) specifically delving into the varieties of salient L1 (Chinese) features found from learners' second language (English) written productions. Thus, the objective of the present study aims at detecting the various categories of L1 features found in learners' L2 writings.

The research aims to look at the following questions.

RQ1. Which prepositions were misused the most?

RQ2. Which L1 features occurred in L2 learners' misuse of prepositions?

\section{Methodology}

\section{Participants}

Undergraduate EFL learners from two English writing classes participated in the study. During the time of the study, the participants were attending the second semester of Basic English Writing class. In the second semester, the two classes were required to write weekly journals as home assignments. The length of each entry ranged from 250 to 300 words. According to their journals, all participants showed evident of their proficiency to compose at least a paragraph-length of English writing.

\section{Instruments}

In the process of detecting the participants' misuse of prepositions, AntConc (version 3.2.4) was adopted to analyze the learners' written data and to establish various categories of preposition misuses that occurred from the learners' data. 
Moreover, Tango (retrieved from http://candle.fl.nthu.edu.tw/collocation/webform2.aspx) was employed to provide suggestions for correction.

\section{Data Analysis}

A 20,017-word database was compiled from two classes of EFL undergraduate learners' journal writings. The instructor encouraged students to adopt newly learned words and to fully express their reflections, thoughts, and intimate feelings without regard for incorrect grammar usages and incorrect sentence structures. This was to prevent learners from producing only simple lexical forms and easy sentence structures in the target language.

Journals were coded in the corpus-analysis for several reasons. First of all, writing journals enabled the participants to express their personal thoughts, frame of mind, and emotions through descriptions of various events, daily incidents, past experiences, and so on. Next, journal writing in nature better encouraged the participants to write autonomously and casually on a wide variety of topics compared to other types of academic writing.

After compiling the data, the ten most frequently used prepositions were drawn out for analysis. For each preposition, an error check was taken into practice. Preposition uses that were found quite vague and difficult to judge whether L1 influence was a factor were not included as an error and thus were not included as a part of the present data analysis.

\section{Results}

After compiling the participants' writings into the database, results of the analysis reveal that a substantial proportion of the words belonged to functions words. Content words, on the other hand, did not appear as frequent (shown in Table 1). While the was reported as the most frequent word used, $I$ and $m y$ was highly ranked as the second and ninth most frequent word respectively. One reason $I$ and $m y$ are ranked within the ten most frequent words may attribute to the genre of the writing texts, which included the participants' personal reflections about their daily events and past experiences.

TABLE 1.

TEN MOST FREQUENT WORDS USED

\begin{tabular}{lll|lll}
\hline Rank & Word & Frequency & Rank & Word & Frequency \\
\hline 1 & the & 828 & 6 & of & 305 \\
\hline 2 & $\boldsymbol{I}$ & 765 & 7 & is & 284 \\
\hline 3 & to & 639 & 8 & in & 279 \\
\hline 4 & and & 501 & 9 & my & 269 \\
\hline 5 & a & 397 & 10 & was & 226 \\
\hline
\end{tabular}

The ten most frequently used prepositions were analyzed through AntConc. In terms of frequency, results show that to, of, and in were the three most frequently used prepositions. Elicited from the database, about, at, and from occurred 55 times respectively (ranked as number nine).

To respond to the first research question, the identified misuses were calculated and presented in numbers of percentage. According to error rate, by $(22.22 \%)$ appeared to be misused most frequently, followed by at $(10.91 \%)$, in $(8.60 \%)$, to $(6.73 \%)$, and for $(6.67 \%)$. Results are presented in Table 2.

TABLE 2.

FREQUENCY AND ERROR RATE OF PREPOSITIONS

\begin{tabular}{llll}
\hline Prepositions & $\begin{array}{l}\text { Frequency Rank } \\
\text { (Times of occurrence) }\end{array}$ & Error Rate & $\begin{array}{l}\text { Rank of Error } \\
\text { Rate }\end{array}$ \\
\hline to & $\mathbf{1 ( 6 4 9 )}$ & $\mathbf{6 . 7 3 \%}$ & $\mathbf{4}$ \\
\hline of & $2(305)$ & $4.26 \%$ & 8 \\
\hline in & $3(279)$ & $8.60 \%$ & 3 \\
\hline for & $4(135)$ & $6.67 \%$ & 5 \\
\hline with & $5(110)$ & $3.64 \%$ & 9 \\
\hline on & $6(88)$ & $5.68 \%$ & 6 \\
\hline as & $7(77)$ & $2.6 \%$ & 10 \\
\hline up & $8(58)$ & $1.72 \%$ & 12 \\
\hline about & $9(55)$ & $5.45 \%$ & 7 \\
\hline at & $9(55)$ & $10.91 \%$ & 2 \\
\hline from & $9(55)$ & $1.8 \%$ & 11 \\
\hline by & $10(54)$ & $22.22 \%$ & 1 \\
\hline
\end{tabular}

Results reveal that in, to, and for appeared with high frequency usages; the ratio of errors made was $8.96 \%$ (25 occurrences), $6.73 \%$ (43 occurrences), and $6.67 \%$ (9 occurrences) respectively.

On the contrary, misuses for about, as, from, and up did not show salient features of L1, thus are not included in discussion on the occurrence of L1 features.

To proceed, the second research question explores which L1 features were detected among the misuse of prepositions. According to the corpus data, features of L1 were found when using the prepositions by, at, in, to, for, on, of, and with. Table 3 provides a summary of the usages of these prepositions and presents sentences produced by the participants. The usages of by, at, in, to, for, on, of, and with will be discussed in the following section respectively. 
TABLE 3 .

DETECTION OF L1 FEATURES

\begin{tabular}{|c|c|}
\hline Preposition & Sentences \\
\hline by & $\begin{array}{l}\text { 1. } \text { was scared by the movie (1) } \\
\text { 2. not convenient for use by lacking menu button (13) } \\
\text { 3. general tofu in other place by frying (16) } \\
\text { 4. He was grown by a family (29) } \\
\text { 5. he wanted to find her out by the image in his mind (30) } \\
\text { 6. acquainted with a beautiful girl by playing game (53) }\end{array}$ \\
\hline at & $\begin{array}{l}\text { 1. } \text { we were walking at there (2) } \\
\text { 2. I just got salary at that day (4) } \\
\text { 3. At last weekend, I go to (17) } \\
\text { 4. } \quad \text { because I at small has lived here (19) } \\
\text { 5. At this activity, we can improve (29) } \\
\text { 6. }\end{array}$ \\
\hline in & $\begin{array}{l}\text { 1. In these weeks (64) } \\
\text { 2. the ambience in there (the ambience there) (125) } \\
\text { 3. do the homework in class in usual time (177) } \\
\text { 4. English class in our campus (184) } \\
\text { 5. In the narrow campus were ancient buildings (209) } \\
\text { 6. in my heart in that day (in my heart that day) (\#260) } \\
\text { 7. lots of couple in there (281) } \\
\text { 8. we were asked to gather in a place first (285) } \\
\text { 9. mountain in their campus (288) } \\
\text { 10. the cats in here came from an animal holding center (292) } \\
\text { 11. the adopt rule in here was strict (293) } \\
\text { 12. In the Christmas time (295) } \\
\text { 13. was born in December } 25 \text { (305) } \\
\text { 14. In the first day (331) }\end{array}$ \\
\hline to & 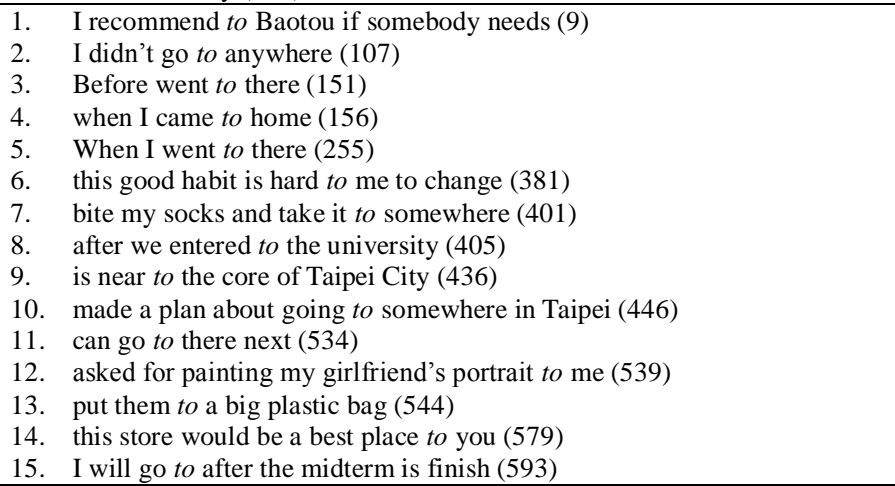 \\
\hline for & $\begin{array}{ll}\text { 1. } & \text { just live for parents }(24) \\
\text { 2. } & \text { in order to prepare this mid-term exam }(26 ; 355 ; 602 ; 610) \\
\text { 3. } & \text { was assigned to the fourth team for } \text { playing games }(140)\end{array}$ \\
\hline on & $\begin{array}{l}\text { 1. } \quad \text { on the present moment (19) } \\
\text { 2. I was on job (20) }\end{array}$ \\
\hline of & $\begin{array}{l}\text { 1. This reunion was worth because I can learn from the talking of everybody. (2) } \\
\text { 2. I joined the wedding ceremony of my cousin (11) } \\
\text { 3. travel of the plan (45) } \\
\text { 4. the teacher of English speech (53) } \\
\text { 5. ignore the road of view and the people we met (59) } \\
\text { 6. we can improve relation of each other by cooperation (138) } \\
\text { 7. baseball field of themselves (189) } \\
\text { 8. I need a environment of English (191) } \\
\text { 9. confused about the reason of studying (205) } \\
\text { 10. the other word of illustrations (255) }\end{array}$ \\
\hline with & $\begin{array}{l}\text { 1. I think he is nothing different with us (14) } \\
\text { 2. It's a story with family-ship, friendship (21) } \\
\text { 3. you can marry with foreign (53) } \\
\text { 4. I have to accompany with him (112) }\end{array}$ \\
\hline
\end{tabular}

\section{Usages of $b y$}

Liu (2004) mentioned that learners tend to use by to express Chinese expressions for “透過”and“用.” The usage for “透過” (through, by, or from) was also found in the present study, for example, “he wanted to find her out by (透過) the image in his mind" and "acquainted with a beautiful girl by (透過) playing a game." Moreover, findings of this study reveal that learners also use by to express Chinese expressions for “被”(used before the main verb to express the passive), for instance, "was scared by (被) the movie," "He was grown by (被) a family." In some cases, by was used to 
express “由於” (owing to), for example, “not convenient for use by (由於) lacking menu button.” The occurrences of by are categorized in Table 4.

TABLE 4

USAGES OF $B Y$

\begin{tabular}{lll}
\hline Native expression & Sentences & Suggestions \\
\hline $\begin{array}{l}\text { 透過、用 } \\
\text { (through, by, or from) }\end{array}$ & $\begin{array}{l}\text { he wanted to find her out by the image in his mind } \\
\text { acquainted with a beautiful girl by playing a game } \\
\text { general tofu in other place by frying }\end{array}$ & $\begin{array}{l}\sim \text { from the image } \\
\text { from playing } \\
\sim \text { are fried }\end{array}$ \\
\hline $\begin{array}{l}\text { 被 } \\
\begin{array}{l}\text { (used before the main verb to } \\
\text { express the passive) }\end{array}\end{array}$ & $\begin{array}{l}\text { was scared by the movie } \\
\text { He was grown by a family }\end{array}$ & $\begin{array}{l}\text { the movie scared me } \\
\text { A family brought him up } \\
\text { (owing to })\end{array}$ \\
\hline
\end{tabular}

\section{Usages of $a t$}

Huang and Chen (2011) reported that Chinese and Taiwanese learners generally encounter difficulty using in, on, and at correctly. One reason is that the three prepositions can be used to express “在” in Chinese which indicates time or place. In the present study, misuses for at occurred most often when associated with time, places, and activities (shown in Table 5).

TABLE 5.

USAGES OF $A T$

\begin{tabular}{lll}
\hline Native expression & Sentences & Suggestions \\
\hline $\begin{array}{l}\text { 在 時間(時候) } \\
\text { (to present time) }\end{array}$ & $\begin{array}{l}\text { I just got salary at that day } \\
\text { At last weekend, I go to } \\
\text { because I at small has lived here }\end{array}$ & $\begin{array}{l}\text { on that day } \\
\text { (omit) } \\
\text { because I lived here } \text { when I was } \\
\text { small }\end{array}$ \\
\hline $\begin{array}{l}\text { 在 地方 } \\
\text { (to present places) }\end{array}$ & $\begin{array}{l}\text { When you arrived at here } \\
\text { we were walking at there }\end{array}$ & $\begin{array}{l}\text { (omit) } \\
\text { (omit) }\end{array}$ \\
\hline $\begin{array}{l}\text { 在 活動 } \\
\text { (to present activities) }\end{array}$ & At this activity, we can improve & From this activity $~$ \\
\hline
\end{tabular}

\section{Usages of in}

According to the analysis, in was often misused when associated with place and time, for example, "in these weeks" and "the ambience in there." Among the misuses, in-place was misused the most, for example, "in there/here" (four occurrences) and "in campus" (two occurrences). Features of L1 was detected here because "in" may refer to “在”which is often followed by time or place, for example, 在學校 (at school) or 在週末 (on the weekend). However, in L2, the prepositions may differ according to the following place or time. The categorization of uses and sentence examples are shown in Table 6.

TABLE 6

USAGES OF IN

\begin{tabular}{|c|c|c|}
\hline Native expression & Sentences & Suggestions \\
\hline $\begin{array}{l}\text { 在 時間 } \\
\text { (to present time) }\end{array}$ & $\begin{array}{l}\text { In these weeks } \\
\text { do the homework in class in usual time } \\
\text { in my heart in that day } \\
\text { In the Christmas time } \\
\text { was born in December } 25 \\
\text { In the first day }\end{array}$ & $\begin{array}{l}\text { (omit) } \\
\sim \text { usually } \\
\sim \text { on that day } \\
\text { At } \text { Christmas time } \\
\sim \text { on December } 25 \\
\text { On the first day }\end{array}$ \\
\hline $\begin{array}{l}\text { 在 地方 } \\
\text { (to present places) }\end{array}$ & $\begin{array}{l}\text { the ambience in there } \\
\text { lots of couple in there } \\
\text { the cats in here came from an animal holding center } \\
\text { the adopt rule in here was strict } \\
\text { English class in our campus } \\
\text { In the narrow campus were ancient buildings } \\
\text { mountain in their campus } \\
\text { we were asked to gather in a place first }\end{array}$ & $\begin{array}{l}\text { (omit) } \\
\text { (omit) } \\
\text { (omit) } \\
\text { (omit) } \\
\sim \text { on our campus } \\
\text { On } ~ \\
\sim \text { on their campus } \\
\sim \text { at a place first }\end{array}$ \\
\hline
\end{tabular}

\section{Usages of to}

According to the data, to was often used with anywhere, somewhere, there, and home. These cases show features of L1 because to can refer to “去” (indicating to go somewhere). In L1, “去” is often followed by a place (a destination) including “去任何地方” (anywhere), “去某個地方” (somewhere), “去那裡” (there), and “去家裡” (home). However, these grammatical structures are not appropriate uses in L2 but often are lexical reflections of learners' L1 usages. 
Moreover, examples from the data show that there were many occurrences of to used to express “對於” (about, for, regarding), “為了” (for, for the sake of, for the intention to), “於” (in, at, on, by, or from) in Chinese (examples are shown in Table 7).

TABLE 7.

USAGES OF TO

\begin{tabular}{|c|c|c|}
\hline Native expression & Sentences & Suggestions \\
\hline $\begin{array}{l}\text { 去 } \\
\text { (to go somewhere) }\end{array}$ & $\begin{array}{l}\text { I recommend to Baotou if somebody needs } \\
\text { I didn't go to anywhere } \\
\text { Before went to there } \\
\text { when I came to home } \\
\text { When I went to there } \\
\text { bite my socks and take it to somewhere } \\
\text { after we entered to the university } \\
\text { is near to the core of Taipei City } \\
\text { made a plan about going to somewhere in Taipei } \\
\text { can go to there next } \\
\text { I will go to after the midterm is finish }\end{array}$ & $\begin{array}{l}\text { (omit) } \\
\text { (omit) } \\
\text { (omit) } \\
\text { (omit) } \\
\text { (omit) } \\
\text { (omit) } \\
\text { (omit) } \\
\text { (omit) } \\
\text { (omit) } \\
\text { (omit) } \\
\sim \text { go there after }\end{array}$ \\
\hline $\begin{array}{l}\text { 對於 (人或事) } \\
\text { (about, for, regarding) }\end{array}$ & $\begin{array}{l}\text { this good habit is hard to me to change } \\
\text { this store would be a best place to you }\end{array}$ & $\begin{array}{l}\sim \text { hard for me to } \\
\sim \text { place for you }\end{array}$ \\
\hline $\begin{array}{l}\text { 為了 } \\
\text { (for, for the sake of, for the } \\
\text { intention to) }\end{array}$ & asked for painting my girlfriend's portrait to me & $\sim$ portrait for me \\
\hline $\begin{array}{l}\text { 於 } \\
\text { (in, at, on, by, or from) }\end{array}$ & put them to a big plastic bag & $\sim$ them in a big \\
\hline
\end{tabular}

\section{Usages of for}

Features of L1 was found when learners used for to express “準備” (to prepare) and “為了” (for the sake of, for the intention of) in Chinese. Generally, “準備” refers to prepare, thus it was found that for was often missing (examples are shown in Table 8).

TABLE 8.

USAGES OF FOR

\begin{tabular}{lll}
\hline Native expression & Sentences & Suggestions \\
\hline $\begin{array}{l}\text { 準備 } \\
\text { (to prepare) }\end{array}$ & in order to prepare this mid-term exam & $\sim$ prepare for \\
\hline $\begin{array}{l}\text { 為了 } \\
\begin{array}{l}\text { (for the sake of, for the } \\
\text { intention of) }\end{array}\end{array}$ & just live for parents & $\begin{array}{l}\text { lead a life according to his/her parents' } \\
\text { will } \\
\text { fourth team to play the game }\end{array}$ \\
\hline
\end{tabular}

\section{Usages of on}

Learners' usages of on were similar to their usages of at and $i n$. These prepositions often confuse learners because at, in and on can be used to express “在” in Chinese. Moreover, results reveal that on was also misused when associated with time as well as with concepts related to be in the process of something, which can be expressed by “在” in the learners' L1, for example, “I was on job.” The results are listed in Table 9 below.

TABLE 9

USAGES OF $O N$

\begin{tabular}{lll}
\hline Native expression & Sentences & Suggestions \\
\hline $\begin{array}{l}\text { 在 時間 } \\
\text { (to present time })\end{array}$ & on the present moment & at \\
\hline $\begin{array}{l}\text { 在 } \text { 工作 } \\
\text { (concept related to job) }\end{array}$ & I was on job & I was working / I was on duty \\
\hline
\end{tabular}

\section{Usages of $o f$}

Interestingly, results reveal that learners prefer using the of-noun structure when indicating possession in their sentences. Although not all occurrences are incorrect, some of the uses are quite redundant (e.g., I need an environment of English.) and are provided suggestions to enhance the fluency of the sentences (e.g., I need an English learning environment). As shown in Table 10 below, the majority of the usages can be explained as “ 的” (to indicate possession, origin, or association) in L1. 
TABLE 10.

USAGES OF $O F$

\begin{tabular}{|c|c|c|}
\hline Native expression & Sentences & Suggestions \\
\hline $\begin{array}{l}\text { 的 } \\
\text { (to indicate possession, } \\
\text { origin, or association) }\end{array}$ & $\begin{array}{l}\text { This reunion was worth because I can learn from the } \\
\text { talking of everybody. } \\
\text { I joined the wedding ceremony of my cousin } \\
\text { travel } o f \text { the plan } \\
\text { the teacher } o f \text { English speech } \\
\text { ignore the road } o f \text { view and the people we met } \\
\text { we can improve relation } o f \text { each other by cooperation } \\
\text { baseball field of themselves } \\
\text { I need an environment } o f \text { English } \\
\text { confused about the reason } o f \text { studying }\end{array}$ & $\begin{array}{l}\text { Ｉ can learn from everybody's sharing. } \\
\sim \text { my cousin's wedding ceremony } \\
\text { itinerary of the trip } \\
\sim \text { speech teacher (omit) } \\
\sim \text { view of the road } \\
\sim \text { our relationship } \\
\text { their baseball field } \\
\sim \text { an English learning environment } \\
\sim \text { reasons for studying }\end{array}$ \\
\hline
\end{tabular}

\section{Usages of with}

Last but not least, not many misuses were found when using the preposition with. However, few features of L1 were detected. According to the learners' productions, with is often used to express “跟” or “有” (to follow, to accompany, to have) in Chinese. The examples are presented in Table 11.

TABLE 11.

USAGES OF WITH

\begin{tabular}{lll}
\hline Native expression & Sentences & Suggestions \\
\hline $\begin{array}{l}\text { 跟 } \\
\text { (to follow, to accompany) }\end{array}$ & $\begin{array}{l}\text { I think he is nothing different with us } \\
\text { you can marry with foreign } \\
\text { I have to accompany with him }\end{array}$ & $\begin{array}{l}\sim \text { different from } \sim \\
\text { (omit) }\end{array}$ \\
\hline 有 & It's a storyit $)$ a foreigner \\
(to have) & & It's a story about family and friendship. \\
\hline
\end{tabular}

\section{DISCUSSION}

The objective of the present study aims at investigating the occurrence of salient L1 (Chinese) features found in learners' L2 (English) written productions. To begin with, according to the error rates, results reveal the top ten misused prepositions, including by, at, in, to, for, on, about, of, with, as, from, and up (prepositions are listed according to error rates from high to low). Learners made least mistakes when using the prepositions as, from, and up. It was interestingly found that most of these prepositions were associated with collocations. These collocations were accurate and errorless, for instance, "as usual," "as well", "regarded as," "such as," "as a result," "as far as," "as well as," "might as well," "as best as he can," "as a matter of fact," "comes from," "different from," "escape from," "hear from," "learn from," "started from," "suffered from," "keep away from," "bring up," "catch up," "cheer up," "clean up," "curl up," "dress up," "get up," "grow up," "heating up" "jump up," "lining up," "make up," "met up," "pick up," "stayed up," "woke up," and "to sum up." The results support the claim that producing collocations enhances comprehensive and fluent writing output and decreases misuses. Correspondingly, the interference of EFL learners' native language in this situation did not produce negative transfer. For other prepositions, not many collocations patterns were found.

Second, the features of L1 were detected and categorized among the misuse of prepositions for by, at, in, to, for, on, of, with. Salient L1 features were not found from the data when learners used prepositions including about, as, from, and up. By was ranked as the preposition with the highest error rate. Liu (2004) found that learners tend to use by to express Chinese expressions for “透過” and “用” (through, by, or from), while in the present study, the participants also used by to convey expressions for “被” (used before the main verb to express the passive) and “由於” (owing to). Because of its wide variety in usage and meaning in Chinese, it is easy to cause confusions for EFL learners.

Third, in the present study, prepositions at, in, and on were found most often misused to express the Chinese expression “在” which can be used in L1 to indicate time, place, space, to be present, to be in the process of, and so on. To be more specific, features of L1 were detected when at was associated with time (e.g., I just got salary at that day. 我在那一天領到薪水。), place (e.g., When you arrived at here. 當你到達(在這裡 ), and activity (e.g., At this activity, we can improve. 在這活動裡,我們能進步。) Moreover, the usage of in was also found most often misused when indicating time and place, for example, “In the first day, ... (在第一天, ...)" and “...the ambience in there (在那裡的氣 氛...)"(refer to Table 6 for more examples). Similarly, some learners misused on when indicating time, for example, “...on the present moment (在目前的時間....). Another occurrence was found when learners intend to express “在” in Chinese to imply in the process of something, for example, “I was on job (我在工作).” In Chinese context, “在” is widely used in general situations including time, places, in the process of, and so on; thus, differentiating different 
situations for using prepositions at, in, and on may take extra effort for EFL learners. The results also correspond to Huang and Chen (2011) who reported that Chinese and Taiwanese learners generally encounter difficulty using in, on, and at correctly.

Next, the preposition to was the most frequently used preposition on the table according to the data. Surprisingly, learners did not commit considerable errors. Yet, the majority of L1 features and misuses were found when EFL learners associated to with places, specifically speaking, words like (to ) anywhere, somewhere, there, and home. Overall, L1 features used with to include “去” (indicating to go somewhere), “對於” (about, for, regarding), “為了” (for, for the sake of, for the intention to), and “於” (in, at, on, by, or from). Results fully support Liu's (2004) claims that errors of to were detected as a characteristic usage of L1 transfer for Chinese learners.

Another salient feature of L1 was also detected when learners used the preposition for. Previous research mentioned that Chinese learners often use for to express “為了” (for the sake of, for the intention of) (Liu, 2004) which was also found in the present study. Although for shares similar meanings with “為了," their grammatical usages are not consistently equivalent. During some situations, they are not replaceable, for example, “...just live for parents (為 $了$ 過 父母的志向生活).” The writer's intention was “...lead a life according to my parents' will.” In such a case, the logical meanings do not match although the L1 and L2 interpretations coordinate. To enhance EFL learners' understanding for such cases, teachers could provide different context with different usages to help guide EFL learners. Rather than solely teaching a preposition, teachers could provide different descriptions to express similar meanings.

Last but not least, according to the data, there were not considerable errors made with the prepositions of and with. However, signs of L1 features such as direct translations were identified, for example, “travel of the plan (旅行的計

劃)," “ignore the road of the view...(忽略路上的景色...)," and so on (examples are presented in Table 10). Although not all cases present incorrect grammar, the lexical structures are quite redundant. It was also found that learners prefer using the of-noun structure when indicating possession in their sentences, for instance, "I need an environment of English" (redundant); "I need an English learning environment" (better). Furthermore, with was often associated with the L1 expression “跟” and “有”. This is similar with the usage of for, when the L2 production does not fully convey the message; yet, the L1 and L2 interpretations coordinate.

To sum up, results of the present study demonstrate features of L1 among EFL learners' use of prepositions. The emergence of L1 features in EFL learners' productions may imply that learners unconsciously seek their L1 for guidance during writing. Thus, guidance while learning and engaging a variety of contexts are means to enhance learners' knowledge for prepositions and to better perform writings with correct usages. The results of the study could be applied in instruction to raise learners' awareness as well as to provide reference for language teachers and educators.

\section{Implications}

The implications of the study suggest that teachers and instructors provide guidance while learning and increase the engagement of a variety of contexts to enhance learners' knowledge for prepositions and to better perform writings with correct usages. Moreover, raise learners' awareness through explicit instruction and rather than solely teaching a single preposition, teachers could provide alternative descriptions to express similar meanings. Furthermore, encourage EFL learners to take use of prepositions through online collocational corpora may also assist individual and autonomous learning, for example, the British National Corpus [http://www.natcorp.ox.ac.uk], and the Michigan Corpus of Academic Spoken English [http://quod.lib.umich.edu/cgi/c/corpus/corpus?c=micase;page=simple] (Huang, 2010).

\section{REFERENCES}

[1] Anthony, L. (2012). AntConc (version 3.2.4) [Computer software]. Tokyo, Japan: Waseda University (accessed 10/6/2013).

[2] Barrett, N. E., \& L.-m. Chen. (2011). English article errors in Taiwanese college students' EFL writing. Computational Linguistics and Chinese Language Processing, 16(3-4), 1-20.

[3] Brender, A. (2002). The effectiveness of teaching articles to (-ART) students in EFL classes using consciousness raising methods. Doctoral dissertation, Temple University.

[4] Bennui, P. (2008). A study of L1 interference in the writing of Thai EFL students. Malaysian Journal of ELT Research, 4, 72-102.

[5] Chan, A. Y. W. (2010). Toward a taxonomy of written errors: Investigation into the written errors of Hong Kong Cantonese ESL learners. TESOL Quarterly, 44(2), 295-319.

[6] Chodorow, M., M. Gamon \& J. Tetreault. (2010). The utility of article and preposition error correction systems for English language learners: Feedback and assessment. Language Testing, 27(3), 419-436.

[7] Chodorow, M., J. R. Tetreault \& N.-R. Han. (2007). Detection of grammatical errors involving prepositions. Proceedings of the $4^{\text {th }}$ ACL-SIGSEM Workshop on Prepositions, Prague, Czech Republic.

[8] Dalgish, G. (1985). Computer-assisted ESL research and courseware development. Computers and Composition, 2(4), 45-62.

[9] Diab, N. (1997). The transfer of Arabic in the English writings of Lebanese students. The ESPecialist, 18(1), 71-83.

[10] Huang, L.-S. (2010). The potential influence of L1 (Chinese) on L2 (English) communication. ELT Journal, 64(2), 155-164.

[11] Huang, Y. C. \& H. J. Chen. (2011). A study on prepositional errors in Taiwanese and Chinese learners' English corpora. 
Unpublished master's thesis, National Taiwan Normal University, Taiwan, R.O.C.

[12] Izumi, E., K. Uchimoto, T. Saiga, T. Supnithi \& H. Ishara. (2003). Automatic error detection in the Japanese learner's English spoken data. Companion Volume to the Proceedings of the $41^{\text {st }}$ Annual Meeting of the Association for Computational Linguistics (ACL).

[13] Kohn, K. (1986). The analysis of transfer. In E. Kellerman, and M. S. Smith (Eds.), Crosslinguistic influence in second language acquisition (pp.21-34). New York: Pergamon Press Inc.

[14] Liu, F. (2004). A computer-assisted error analysis of prepositional uses in non-English majors' writing. Unpublished master thesis, Huazhong University of Science and Technology, China.

[15] Mahmoodzadeh, M. (2012). A cross-linguistic study of prepositions in Persian and English: The effect of transfer. Theory and Practice in Language Studies, 2(4), 734-740.

[16] Odlin, T. (1989). Language transfer: Cross-linguistic influence in language learning. Cambridge: Cambridge University Press.

[17] Ringbom, H. (1992). On L1 transfer in L2 comprehension and L2 production. Language Learning, 42(1), 85-112.

[18] Sersen, W. J. (2011). Improving writing skills of Thai EFL students by recognition of and compensation for factors of L1 to L2 negative transfer. US-China Education Review, A(3), 339-345.

[19] Tango. (no date). Taiwan: National Tsing Hua University. Retrieved from http://candle.fl.nthu.edu.tw/collocation/webform2.aspx (accessed 13/6/2013).

[20] Tetreault, J. R. \& M. Chodorow. (2008). The ups and downs of preposition error detection in ESL writing. Proceedings of the $22^{\text {nd }}$ International Conference on Computational Linguistics, Manchester, UK.

Huei-Chun Yuan is currently pursuing her PhD in TESOL at National Taiwan Normal University (Taipei). She received her M.A. degree in Applied Foreign Languages from National Taiwan University of Science and Technology (Taipei) in 2009. She is also an ESL instructor with six years of teaching experience. Her research interests include language assessment, short messaging service (SMS) language, and academic writing. 